\title{
(9) \\ Archives Of Breast

DOI: 10.32768/abc.202183162-173

Marine Cyclic Dipeptide Cyclo (L-Leu-L-Pro) Protects Normal Breast Epithelial Cells from tBHP-induced Oxidative Damage by Targeting CD151

\author{
Deepak KGK ${ }^{a}$, Seema Kumari ${ }^{a}$, RamaRao Malla*a \\ ${ }^{a}$ Cancer Biology Lab, Department of Biochemistry and Bioinformatics, GIS, GITAM (Deemed to be University), \\ Visakhapatnam-530045, Andhra Pradesh, India
}

\section{ARTICLE INFO \\ Received: \\ 12 January 2021 \\ Revised: \\ 14 April 2021 \\ Accepted: \\ 18 April 2021}

Key words:

Actinobacteria, apoptosis,

cytoprotective,

DNA damage,

MCF-12A cells.

\section{ABSTRACT}

Background: Oxidative stress plays a key role in breast carcinogenesis. Cyclo (L-Leu-L-Pro) (CLP) is a homodetic cyclic dipeptide with 2,5-diketopiperazine scaffold isolated from marine actinobacteria. This study aimed to evaluate the protective activity of CLP and linear - (L-Leu-L-Pro) (LP) from tert-butyl hydroperoxide (tBHP)-induced damage using normal breast epithelial cell line model (MCF-12A).

Methods: The cytoprotective activity was evaluated by detecting the changes in intracellular ROS, mitochondrial superoxide, hydroxyl radical, hydrogen peroxide, and lipid peroxidation detection assays as well as cytotoxic assays of MTT, LDH assays and phase contrast microscopy. Genoprotective activity was evaluated by (Apurinic/Apyrimidinic) AP site, alkaline Comet, and 8-hydroxy-2deoxyguanosine assays.

Results: The marine cyclic peptide, CLP, significantly protected MCF-12A cells by scavenging tBHP induced intracellular ROS such as super oxide, hydroxyl radicals and hydrogen peroxide, and by reducing the cytotoxicity and genotoxicity effect compared to LP. Moreover, the results showed that CD151 gene silencing by shRNA significantly reduced the overexpression of CD151, tBHP-induced ROS generation, cytotoxicity and genotoxicity in MCF-12A cells. The overexpression of CD151 caused increased levels of cytochrome P450, but was reduced following the application of CD151shRNA and CLP which led to elevated levels of intracellular ROS.

Conclusion: In the present study we noticed that CD151 gene silencing by shRNA and treatment with CLP have similar effects on reducing the intracellular ROS. This study uncovers the protective activity of CLP against a CD151mediated oxidative stress-induced cellular damage. Our observations suggest that the anti-stress and anti-inflammation properties of CLP might have implications in cancer and are worth testing in cancer cell lines and tumor cells.

\section{Introduction}

Oxidative stress plays a key role in breast carcinogenesis. ' The prooxidant, tert-butyl hydroperoxide (tBHP), is extensively used as an exogenous stress inducer. ${ }^{2}$ tBHP mimics oxidative

\footnotetext{
* Address for correspondence:

Prof. Rama Rao Malla, PhD

Department of Biochemistry and Bioinformatics,

GIS, GITAM (Deemed to be University), Visakhapatnam-530045 Tel: $91-7386168249$

Email: dr.rrmalla@gmail.com
}

stress by resembling products of oxidative stressmediated lipoperoxidation ${ }^{3}$ and has extensively been used as an inducer of ROS-mediated oxidative stress. ${ }^{4}$ Typically, two pathways, cytochrome P450 (CYP), and glutathione oxidase are involved in tBHP metabolism, and tBHP metabolites are known to reduce mitochondrial function by inducing oxidative stress. ${ }^{5}$ tBHP also induces oxidative stress through NF$\mathrm{kB}$ pathway. ${ }^{6}$ Moreover, tBHP is a well-studied oxidative stress-mediated tumor promoter. $^{7} 8$ The metabolites of tBHP are known to promote free radical 
mediated carcinogenesis in skin cells ${ }^{9}$, epidermal cells ${ }^{10}$, fibroblasts and keratinocytes. ${ }^{11}$ Also, it promotes carcinogenesis by inducing the expression of oncogenes in epidermal cells ${ }^{10}$, breast cells ${ }^{12}$, and promote lung tumors. ${ }^{13}$ tBHP promotes cytotoxicity and genotoxicity in various cell lines. ${ }^{14}$ tBHP-mediated oxidative stress triggers EGFR activation by promoting phosphorylation at its tyrosine residues ${ }^{15}$ which causes cellular transformation of epithelial cells. ${ }^{16}$

Our previous study ${ }^{17}$, and another study ${ }^{18}$ demonstrated that CD151, a member of a well-known multicellularity-associated gene family, is associated with EGFR signaling. TSP-15, a human CD151, is linked with ROS generating dual oxidase. ${ }^{19,20}$ A study has reported that ROS generation system requires tetraspanin and they co-occur during evolution. ${ }^{21}$ Another study reported that tetraspanins are essential in the induction of $\mathrm{H}_{2} \mathrm{O}_{2}$ by dual oxidase via forming a complex at the cell surface. ${ }^{19} \mathrm{CD} 151$ is one of the oncogenic members of the tetraspanin family that participates in cancer progression and metastasis by associating with ROS generating proteases, signaling enzymes, GPCRs, cadherins, and proteoglycans. ${ }^{22}$ Recently, we demonstrated that CD151 interacts with EGFR in breast cancer cells. ${ }^{17}$ EGFR is involved in the regulation of oxidative stress. ${ }^{23}$ Using the Chip assay, Chen et al. demonstrated that EGF/EGFR complex directly binds to the promoter of cytochrome P450 (CYP). ${ }^{24}$ The role of members of cytochrome P450 (CYP) has been well reported in the conversion of metabolites into potentially toxic compounds ${ }^{25}$ which can damage cells by forming DNA/protein adducts or by generating ROS. ${ }^{26}$ Also, CYP mediates cytotoxicity and cell death induced by toxic compounds in epithelial cells ${ }^{27,28}$ and drug induced cell death by increasing the LDH leakage in hepatocytes ${ }^{29}$, lipid peroxidation dependent cytotoxicity and apoptosis ${ }^{30}$ as well as arachidonic acid induced cytotoxicity and apoptosis. ${ }^{31} \mathrm{CYP}$ genes are controlled by various regulatory networks and microRNAs ${ }^{32}$, receptors and transcriptional factors at basal levels ${ }^{33}$, heat shock proteins by stabilization ${ }^{34}$, protein-protein interaction ${ }^{35}$ and organization in the lipid membranes. ${ }^{36}$ We speculate that CD151 may be associated with TEM establishment to facilitate cytochrome P450 mediated ROS generation in tBHPinduced cytotoxicity in MCF-12A cells.

Natural products prevent disease progression by scavenging ROS and enhancing the body's natural defense by inhibiting lipid peroxidation or direct interaction with key stress-related signaling molecules. Moreover, they can also control the initiation of carcinogenesis by protecting against DNA damage. ${ }^{37}$ Marine secondary metabolites find clinical applications owing to their antioxidant ${ }^{38,39}$ or protective activity. ${ }^{40,}$ A1 Actinobacteria contribute to $70 \%$ of the known drugs. ${ }^{42}$ Novel peptides with marine sources are under clinical trials due to their antibacterial, anti-inflammatory, and anti-cancer properties. $^{43}$

Cyclic dipeptides are modest peptide derivatives, usually present in nature ${ }^{44}$ and are normally more stable and potent than other cyclic peptides in terms of drug efficacy. Cyclic dipeptides with different biological activities were isolated from marine organisms. ${ }^{45-50}$ They are known to exhibit antifungal ${ }^{51,52}$, antitumor ${ }^{53}$, antiviral $1^{54}$, and antibacterial activities. ${ }^{55,56}$ For instance, cyclo (DTyr-D-Phe) exhibits antioxidant and anti-cancer properties. ${ }^{57}$ Cyclo(His-Pro) was found to activate caspase- 3 and enhance poly(ADP-ribose) polymerase (PARP) cleavage and DNA fragmentation. ${ }^{58}$ The cyclic dipeptides, azonazine, cyclo (His-Pro), 2,5-diketopiperazines, petrocidin A are well known for targeting cancer cells. ${ }^{59} \mathrm{Nilov}$ et al. (2018) demonstrated that cyclo (L-Ala-L-Ala) and cyclo (L-Ala-D-Ala) had sensitize DNA damaging effects of chemotherapeutics in drug resistance cancer cells. ${ }^{60}$

Cyclo(L-Leu-L-Pro) (CLP), a homodetic cyclic peptide belongs to the class of 2,5-diketopiperazines, isolated from marine actinobacteria strain ${ }^{61,62}$, marine Streptomyces $^{63}$, sponge ${ }^{64}$ and halobacterium. ${ }^{65}$ It is noted for vast biological actions including antimicrobial $^{66}$, antifouling ${ }^{46}$, antioxidant ${ }^{67}$, cytotoxic $^{68,69}$, anti-mutagenic activities ${ }^{70}$, anticarcinogenic $^{71}$ and anti-migratory potential of TNBC cells. ${ }^{72}$ CLP's biological role was reported as a nutrient by the human metabolic database (https://hmdb.ca/metabolites/ HMDB0034276), although cytoprotective activity was not observed. Therefore, we evaluated CLP's cytoprotective and genoprotective activities against tBHP-induced damages in MCF-12A cell line model targeting CD151-EGFR signaling pathway.

\section{Methods}

\section{Culture and Treatment}

MCF-12A cells were obtained from ATCC and maintained in DME medium containing $10 \%$ FBS at $37^{\circ} \mathrm{C}$ in an incubator under $5 \% \mathrm{CO}_{2}$ atmosphere. To evaluate radical scavenging activity, MCF-12A cells $\left(1 \times 10^{4}\right.$ cells/well $)$ in a 96-well plate were pretreated overnight with tBHP $(0.25 \mathrm{mM})$ and then with CLP, ascorbic acid (AA) and linear L-Leucyl-L-Proline (LP) $(0,20,40,60,80$ and $100 \mu \mathrm{M})$ for 24 hours.

tBHP, CLP, LP and AA were prepared in $0.1 \%$ DMSO in DMEM. To evaluate cytoprotective and genoprotective activities, MCF-12A cells were pretreated with CLP $(0,20,40,60,80$ and $100 \mu \mathrm{M})$ overnight and then with tBHP $(0.25 \mathrm{mM})$ for 24 hours.

The concentration of CLP that we used was based on our previous studies on TNBC's. ${ }^{17} \mathrm{AA}$ and LP were used as positive controls to compare the radical scavenging, cytoprotective and genoprotective activities of CLP. 


\section{Intracellular ROS detection assay}

The intracellular ROS was computed using DCFDA by cellular ROS detection assay kit as per the manufacturer's instructions (Abcam, Cambridge, USA, ab113851). Briefly, the cell samples were rinsed with PBS, and stained with DCF-DA $(20 \mu \mathrm{M})$ for $30 \mathrm{~min}$. After staining, the samples were washed again with PBS and the fluorescence emitted by the cells was measured at the Ex/Em wavelength $485 / 535 \mathrm{~nm}$ using a spectrofluorometer. The tBHPinduced intracellular ROS scavenging ability was reported as percentage of tBHP treated control.

\section{Mitochondrial superoxide (O2-) detection assay}

The mitochondrial superoxide was measured with a mitochondrial superoxide detection assay kit according to the manufacturer's instructions (Abcam, Cambridge, USA, ab219943). The cells were rinsed with PBS and incubated with $100 \mu \mathrm{L}$ of MitoROS-580 staining solution for 1 hour. Next, the fluorescence intensity was measured as outlined above, at the Ex/Em wavelength $540 / 590 \mathrm{~nm}$, and tBHP-induced mitochondrial superoxide scavenging activity was expressed as percentage of tBHP treated control. $^{74}$

\section{Mitochondrial hydroxyl radical detection assay}

The mitochondrial hydroxyl radicals were measured using a mitochondrial hydroxyl radical detection assay kit (Abcam, Cambridge, USA, ab219931). The cells were incubated with assay buffer $(100 \mu \mathrm{L})$ and OH580 staining solution (100 $\mu \mathrm{L}$ ) for 1 hour at $37^{\circ} \mathrm{C}$ after rinsing with PBS. Then, the fluorescence intensity was measured as outlined above. The scavenging ability of mitochondrial hydroxyl radical was expressed as percentage of tBHP treated control.

\section{Intracellular hydrogen peroxide assay}

Intracellular hydrogen peroxides was determined using an $\mathrm{H}_{2} \mathrm{O}_{2}$ cell-based assay kit (Caymen, Michigan, USA, Cat\# 600050). Next, the cells were rinsed with PBS and $10 \mu \mathrm{L}$ of each assay buffer and enzyme reaction solution containing horseradish hydrogen peroxidase and hydrogen peroxide detector (ADHP) was added. Within 5 minutes, the fluorescence emitted by the cells was measured at $\mathrm{Ex} / \mathrm{Em}$ of $530 / 590 \mathrm{~nm}$. The tBHP-induced intracellular hydrogen peroxide scavenging activity was expressed as percentage of tBHP control. ${ }^{75}$

\section{Lipid peroxidation (MDA) assay}

The lipid peroxidation was evaluated using a lipid peroxidation (MDA) assay kit (Abcam, Cambridge, USA, ab118970). Two hundred $\mu \mathrm{L}$ of the treated cell lysis solution was added to each well, homogenized by placing on ice, and centrifuged at $13,000 \mathrm{rpm}$ for 10 minutes. Then the cell lysate (200 $\mu \mathrm{L}$ ) was incubated with $200 \mu \mathrm{L}$ of TBA reagent for 1 h at $95^{\circ} \mathrm{C}$. Next, the absorbance was measured at 532 $\mathrm{nm}$ using a microplate reader. The inhibition of tBHP-induced lipid peroxidation was expressed as percentage of tBHP treated control. ${ }^{76}$

\section{MTTassay}

The treated cells were incubated with MTT reagent $(5 \mathrm{mg} / \mathrm{mL}$ of PBS) for 2 hours. Next, the formazan crystals formed were solubilized by adding $200 \mu \mathrm{L}$ of DMSO. The absorbance was computed using an ELISA reader at $595 \mathrm{~nm}$. The cytoprotective effect was expressed by comparing cytotoxicity with tBHP treated control. ${ }^{72}$

\section{Lactate dehydrogenase (LDH) assay}

Treated cells were rapidly homogenized in LDH assay buffer on ice and cell debris was removed by sedimentation at $10,000 \mathrm{rpm}$ for 15 minuets at $4{ }^{\circ} \mathrm{C}$. The soluble fraction was used for measuring LDH activity by LDH activity assay Kit (Sigma-Aldrich, USA). The protective effect was expressed by comparing the LDH levels with tBHP treated control. $^{77}$

\section{Phase-contrastmicroscopy}

Cells $(3 \times 103 /$ well $)$ in a 96 -well plate were treated with tBHP $(0.25 \mathrm{mM})$ alone or in combination with CLP $(84.21 \mu \mathrm{M})$ or LP $(176 \mu \mathrm{M})$ for 24 hours. After treatment, the cells were washed thrice with serumfree media, and images were captured at $40 \mathrm{X}$ resolution under the inverted phase-contrast microscope.

\section{Detection of AP Sites}

The cellular DNA was extracted from treated and untreated cells. The reaction mixture $[1 \mu \mathrm{g}$ of DNA, $200 \mu \mathrm{l}$ of $10 \mathrm{mM}$ Tris (pH 9), $15 \mu \mathrm{l}$ of $5 \mathrm{M}$ $\mathrm{NaCl}$ ] was incubated with $30 \mu \mathrm{l}$ of avidin-HRP for $60 \mathrm{~min}$ at room temperature (RT). The DNA HRP was extracted by treating with $65 \mu \mathrm{l}$ of $1 \mathrm{mM}$ DAPER for 5 minutes followed by centrifugation for $5 \mathrm{~min}$ at $12,500 \times \mathrm{g}$ at $4{ }^{\circ} \mathrm{C}$. The pellet was washed with $1.4 \mathrm{ml}$ of wash buffer and suspended in $500 \mu \mathrm{l}$ ice-cold $50 \mathrm{mM} \mathrm{Na}$-citrate ( $\mathrm{pH}$ 5.3) by sonication. The HRP activity was determined showing AP sites in DNA-HRP by ELISA method.

Detection of 8-hydroxy-2'-deoxyguanosine (8-OHdG) Competitive ELISA was performed using an 8OHdG ELISA kit, by the protocol of the Cayman Chemicals (USA). The purified DNA was subjected to enzymatic digestion using nuclease $\mathrm{P} 1$ at $50^{\circ} \mathrm{C}$ for $1 \mathrm{~h}$ and with alkaline phosphatase at $37{ }^{\circ} \mathrm{C}$ for 30 minutes. The digested DNA was boiled for 10 minuets and placed on ice for 5 minutes. The hydrolyzed DNA was measured by reading the absorbance at $412 \mathrm{~nm}$. The levels of 8-OHdG were measured and expressed as $\mu \mathrm{g}$ of $8-\mathrm{OHdG} / \mathrm{ml}^{78}$ 


\section{Alkaline Comet assay}

The treated and untreated cells were plated on a slide previously coated three times with low melting agarose $(0.75 \%)$. The slide was then placed in lysing solution at $4{ }^{\circ} \mathrm{C}$ for 1 hour followed by electrophoresis by setting the voltage to $20 \mathrm{~V}$ for 20 min. The slide was then soaked in neutralizing buffer followed by ethanol for 5 minutes. Then the slide was stained with ethidium bromide $(40 \mu \mathrm{l})$. The tail length was measured, and the olive tail movement (OTM) was computed as: (head mean) $x$ tail \% DNA/100.

\section{Cell death by Annexin VELISA method}

After treatment, cell samples were washed with PBS, and apoptotic cells were determined using Annexin V ELISA method. Briefly, cells were incubated with $50 \mu \mathrm{l}$ of annexin $\mathrm{V}$ antibody at $25^{\circ} \mathrm{C}$ for 1 hour. The apoptosis rate was determined as per the manufacturer's instructions (Abcam, USA). ${ }^{79}$

\section{Cell-based ELISA for quantification of Cd151}

After treatment, the cells were washed with PBS and incubated with CD151 primary antibody overnight at $4{ }^{\circ} \mathrm{C}$. After washing off the unbound primary antibody, cells were treated with HRPconjugated secondary antibody specific to CD151 $(100 \mu \mathrm{L})$ and incubated at $37^{\circ} \mathrm{C}$ for $1 \mathrm{~h}$. Following washing the unbound secondary antibody, the cells in each well were incubated with TMB One-Step Substrate Reagent $(100 \mu \mathrm{L})$ at $37^{\circ} \mathrm{C}$ in the dark for $30 \mathrm{~min}$. After stopping the reaction by adding stop solution $(50 \mu \mathrm{L})$, the absorbance was computed using a microplate reader set to $450 \mathrm{~nm}$.

\section{CD151 gene silencing using shRNA}

After overnight seeding of MCF-12A cells $(5 \times 104)$ in a 6 -well plate, the cells were transfected with CD151 shRNA overnight as described by Gayatri et al ${ }^{80,81}$ After transfection, the cells were treated with tBHP $(0.25 \mathrm{mM})$ for 24 hours and intracellular ROS was measured using DCF-DA using cellular ROS detection assay kit, extracellular LDH using LDH assay kit and DNA damage using alkaline comet assay as described above.

\section{CD151 overexpression in $M C F-12 A$ cells}

After overnight seeding of MCF-12A cells $\left(5 \times 10^{4}\right)$ in a 6-well plate, the cells were transfected with $10 \mu \mathrm{g}$ untagged PrecisionShuttle mammalian plasmid encoding CD151(CAT\#: SC319271, OriGene, USA) using TurboFectin Transfection Reagent (TF81001, OriGene) following the manufacturer's protocol. After 24 hours of transfection, the cells were treated with CLP and LP for 24 hours. Then CD151 expression levels were determined by cell-based ELISA, and intracellular ROS, LDH and DNA damage were determined using their specific methods outlined above.
Protein-protein interaction by ClusPro and PyDOCK webserver

The ClusPro is a widely used fully automated protein-protein docking server, which uses direct docking of two interacting proteins (https:// cluspro.bu.edu) ${ }^{82}$ It uses PIPER 16 for the rigid body docking program based on the Fast Fourier Transform (FFT) correlation approach. PyDOCK web server, which uses rigid-body docking orientations generated by FTDock and evaluation is based on electrostatics, de-solvation energy and limited van der Waals interactions. ${ }^{83}$ Using ClusPro and PyDOCK webserver, the interaction between CD151 and cytochrome $\mathrm{p} 450$ was predicted.

Measurement of cytochrome P450 levels by ELISA

After treatment, cell samples were collected by scraping into ice-cold PBS, sedimented by centrifugation at $3000 \mathrm{rpm}$ for $5 \mathrm{~min}$. The cell pellet was suspended in a cell lysis buffer, and the cells were lysed by pipetting up and down 5-10 times. Then the lysate was cleared by removing cell debris using centrifugation at $10,000 \mathrm{rpm}$ for $5 \mathrm{~min}$ at $4{ }^{\circ} \mathrm{C}$. Next, cytochrome P450 levels in the cell lysate were determined by human quantitative sandwich cytochrome P450 ELISA kit (CUSABIO Technology LLC, USA) using cytochrome p450 antibody precoated microplate following the manufacturer's instructions. After removing the unbound substances by washing, the plate was incubated by adding cytochrome P450 antibody conjugated to biotin, followed by HRP conjugated avidin. Finally, the color was developed by incubating with TMB substrate solution. After stopping the color development using a stop solution, the optical density was measured at $450 \mathrm{~nm}$ using a microplate reader.

\section{Statistical analysis}

The data from the experiments were analyzed statistically and represented graphically using Microsoft Excel. To ensure the consistency of the results, each experiment was performed three times, and values were represented as mean $\pm S D(n+3)$. One-way variance analysis was performed to calculate the means of the dependent variable (response) and independent variable (concentration) using NumPy (v 1.1.2) and Google Colab. Student ttest was performed to compare mean values. The statistical significance was set with a confidence level of $95 \%$ and $\mathrm{p}$ value $<0.05 . \mathrm{IC}_{50}$ values were calculated using MS Excel ProPlus (Version 2016).

\section{Results}

Intracellular ROS scavenging ability of cyclo( $L$ Leu-L-Pro)

tBHP $(0.25 \mathrm{mM})$ stimulates augmented oxidative stress in MCF-12A cell line which helps to understand the protective role of CLP in regulating CD151-mediated oxidative stress. The scavenging 
activity of CLP applied at increasing concentrations $(0-100 \mu \mathrm{M})$ against tBHP-induced intracellular ROS production was compared with that of linear dipeptide (LP) and radical scavenger, AA (Figure 1a). The prooxidant tBHP triggered considerable oxidation of $\mathrm{DCFH}_{2}$ to DCF and enhanced intracellular fluorescence intensity in controls. However, CLP treatment decreased the tBHPinduced fluorescence intensity in a dose-dependent manner. Cyclic dipeptide CLP diffuses into the cells through the cell membrane, where it may prevent the generation of ROS required to oxidize intracellular DCFH2 to the fluorescent DCF. tBHP stimulated intracellular ROS generation, scavenged by treatment with CLP. The percent of radical scavenging activity are $17.8 \pm 2.3,32.6 \pm 2.2$, $41.7 \pm 2.3,54.2 \pm 3.4$ and $70.2 \pm 3.3 \%$ with CLP, and the positive control AA exhibited $21.6 \pm 2.5,39.4 \pm 2.3$, $52.4 \pm 2.4,59.3 \pm 3.4$ and $75.3 \pm 3.2 \%$ of radical scavenging activity, while for another positive control LP, the radical scavenging activity was $8.2 \pm 1.2,12.2 \pm 1.3,21.2 \pm 1.3,32.2 \pm 2.4$ and $38.1 \pm 2.4 \%$ at $20,40,60,80$ and $100 \mu \mathrm{M}$, respectively. The $\mathrm{IC}_{50}$ values of CLP, AA and LP for scavenging intracellular ROS were 70.6, 130 and $60.5 \mu \mathrm{M}$, respectively.(Figure 1a) This study demonstrates the concentration-dependent intracellular ROS scavenging activity of the CLP like ascorbic acid, which is higher than that of LP.

Superoxide ion $\left(\mathrm{O}_{2}{ }^{-}\right)$is the most acceptable candidate for causing oxidative stress damage to the cell. ${ }^{8486}$ The oxidative stress causes the escape of electrons from mitochondrial ETC and directly generates the $\mathrm{O}_{2}$ by reacting with molecular oxygen. ${ }^{87}$

${ }^{89}$ The present study observed that tBHP-induced intracellular $\mathrm{O}_{2}$.- was scavenged by $20.8 \pm 2.3,42.6 \pm 2.3$, $52.5 \pm 3.4,63.4 \pm 3.3$ and $85.4 \pm 4.3 \%$ with CLP and $24.6 \pm 2.2,46.3 \pm 2.4,56.2 \pm 3.3,68.5 \pm 4.3$ and $89.4 \pm 4.4 \%$ with $\mathrm{AA}$ and $10.8 \pm 1.8,26.3 \pm 2.4,33.2 \pm 3.4,43.9 \pm 4.1$ and $59.6 \pm 4.8 \%$ with AA at $20,40,60,80$ and $100 \mu \mathrm{M}$ as shown in Figure $1 \mathrm{~b}$. The $\mathrm{IC}_{50}$ of the CLP was $56.0 \mu \mathrm{M}$, LP was $86.4 \mu \mathrm{M}$ and $\mathrm{AA}$ was $50.7 \mu \mathrm{M}$, indicating the potential $\mathrm{O}_{2}$ scavenging ability of CLP close to AA.

Among the reactive oxygen centered species, hydroxyl radicals $(\mathrm{OH})$ cause serious damage to proteins, polyunsaturated fatty acids and DNA and are implicated in radical-mediated pathology. The intracellular $\mathrm{OH}$ scavenging action of CLP was related to intracellular antioxidant ability. The results depicted in Figure 1c show that tBHP- induced intracellular $\mathrm{OH}$ scavenging activity of the CLP was $19.2 \pm 2.3,28.3 \pm 2.3,41.4 \pm 2.3,55.4 \pm 3.4$ and $81.5 \pm 4.4 \%$ whereas AA showed $21.4 \pm 2.3,32.2 \pm 2.3$, $48.4 \pm 3.3,62.4 \pm 3.4$ and $82.8 \pm 4.4 \%$ and LP exhibited $9.8 \pm 1.8,22.6 \pm 2.1,30.5 \pm 2.9,39.4 \pm 3.1$ and $56.4 \pm 3.8 \%$ at $20,40,60,80$ and $100 \mu \mathrm{M}$, respectively. The $\mathrm{IC}_{50}$ of CLP was $66.3 \mu \mathrm{M}$, LP was $93.1 \mu \mathrm{M}$ and $\mathrm{AA}$ was $60.68 \mu \mathrm{M}$, indicating potential intracellular $\mathrm{OH}$ scavenging activity of CLP, similar to AA.
One of the interesting developments in the free radical-mediated pathology is the formation of hydroxyl radicals by the interaction between $\mathrm{O}_{2}$ and $\mathrm{H}_{2} \mathrm{O}_{2}$. Hence, we evaluated the intracellular $\mathrm{H}_{2} \mathrm{O}_{2}$ scavenging activity of the CLP. The study observed that tBHP-induced intracellular $\mathrm{H}_{2} \mathrm{O}_{2}$ scavenging activity with the CLP was $16.9 \pm 2.3,34.6 \pm 2.3$, $45.7 \pm 3.3,56.2 \pm 3.4$ and $72.1 \pm 4.3 \%$, whereas $21.6 \pm 2.5,38.4 \pm 2.3,55.4 \pm 3.5,62.3 \pm 3.4$ and $76.4 \pm 4.3 \%$ with AA, and $8.6 \pm 1.2,16.6 \pm 1.8,28.5 \pm 2.1$, $36.3 \pm 2.9$ and $52.1 \pm 3.2 \%$ with LP at $20,40,60,80$ and $100 \mu \mathrm{M}$, respectively, indicating that intracellular $\mathrm{H}_{2} \mathrm{O}_{2}$ scavenging activity of CLP is similar to that of $\mathrm{AA}$ as shown in Figure 1d. The significant radical scavenging ability may recommend CLP for the treatment of stress associated cancers.

\section{Cytoprotective activity of CLP against tBHP- mediated cytotoxicity}

The current study evaluated the protective ability of the CLP on tBHP stimulated lipid peroxidation in MCF-12A cells. Malondialdehyde (MDA) is the most widely cited lipoperoxidation product instigating from unsaturated lipids of membranes during oxidative stress. The protective effect of CLP was confirmed by lipid peroxidation assay. The percentage of inhibition of tBHP-induced lipid peroxidation by serial concentrations of CLP increased in a dose dependent manner to a maximum of $89.8 \pm 5.3 \%$. This figure stood at $91.8 \pm 7.3 \%$ with AA and $57.8 \pm 4.1 \%$ with LP (Figure 2a). This study also evaluated the impact of the CLP on tBHP-mediated cytotoxicity in MCF-12A cells. The results show that percent of viable cells increased with increasing concentration. Treatment with CLP showed $68.6 \pm 3.2 \%$ viability, which indicates that CLP efficiently enhanced tBHP treated MCF-12A cells viability. Treatment with positive controls like AA and LP showed maximum viability of $74.9 \pm 4.3$ and $33.4 \pm 2.8 \%$, respectively (Figure 2b). Further, the CLP's cytoprotective activity was evaluated by measuring LDH leakage from cell, an indicator of the cell membrane damage. The CLP efficiently blocked tBHP-induced LDH release from MCF-12A cells. The percentage of inhibition of LDH release increased with increasing concentration from 20 to $100 \mu \mathrm{M}$. The maximum inhibition of $\mathrm{LDH}$ release was measured with CLP $(62.8 \pm 3.4 \%)$, AA $(71.5 \pm 4.3 \%)$ and LP $(28.4 \pm 2.1 \%)$ with $\mathrm{IC}_{50}$ of 82.9 $\mu \mathrm{M}, 72.7 \mu \mathrm{M}$ and $174 \mu \mathrm{M}$, respectively (Figure $2 \mathrm{c}$ ). Further, the effect of CLP on tBHP-induced morphology of MCF-12A cells was monitored under phase-contrast microscopy (Figure 2d). The results show that tBHP $(0.25 \mathrm{mM})$ induced morphological changes in MCF-12A cells. However, pretreatment with CLP $(84.2 \mu \mathrm{M})$ significantly protected the MCF12A cells from tBHP-induced morphological changes better than LP $(174 \mu \mathrm{M})$ and AA $(76.6 \mu \mathrm{M})$. These results suggest the potential cytoprotective activity of the CLP. Table 1 shows the data related to 
a)

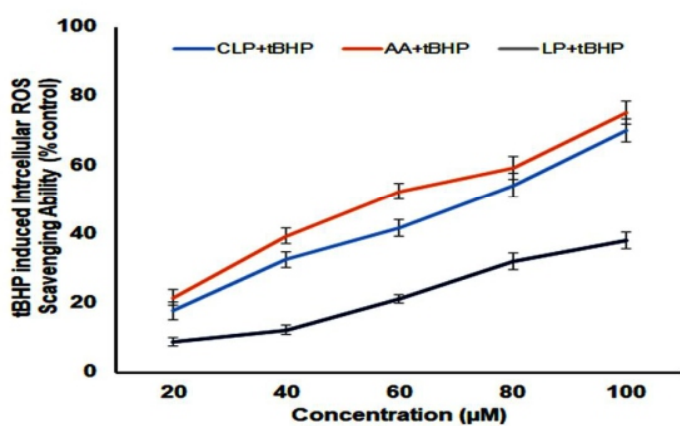

c)

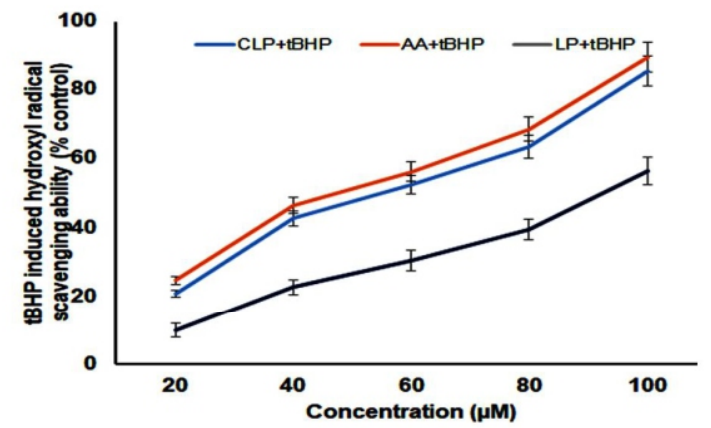

b)

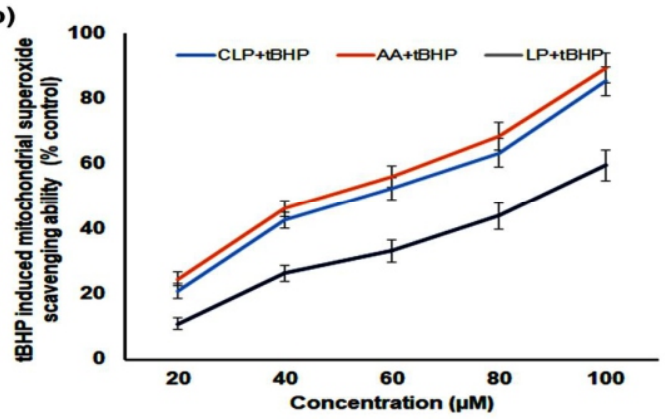

d)

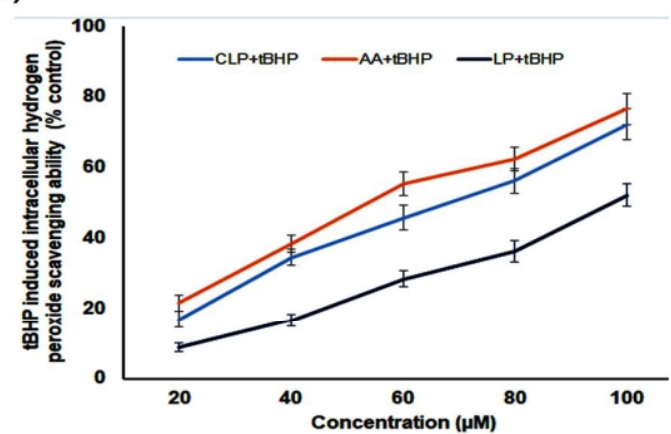

Figure 1. Protective effect of CLP from tBHP-induced intracellular ROS levels in MCF-12A. Cells (1x10 $/$ well) in a 96-well plate were pretreated overnight with $\mathrm{tBHP}(0.25 \mathrm{mM})$ and subsequently with serial concentrations of CLP $(0,20,40,60,80$ and $100 \mu \mathrm{M})$ for $24 \mathrm{~h}$. Only tBHP treated cells were served as untreated control. The fluorescence generated upon conversion of DCFH2 to DCF due to the CLP scavenging activity was measured at the Ex/Em wavelength $485 / 535 \mathrm{~nm}$ using a spectrofluorometer and expressed as \% control. The percent control is defined as: Fluorescence change in CLP treated cells/ tBHP treated cells x100. The same concentrations of ascorbic acid (AA) and linear dipeptide, L-Leucyl-L-Proline (LP) were used as positive controls. The graphs show the protective effect of CLP on tBHP-induced a) intracellular ROS production, b) mitochondrial superoxides, c) mitochondrial hydroxyl radicals and d) intracellular hydrogen peroxide. The cumulative data of each assay were collected from three independent experiments and shown as means $\pm \operatorname{SEM}(\mathrm{n}=3)$.

a)

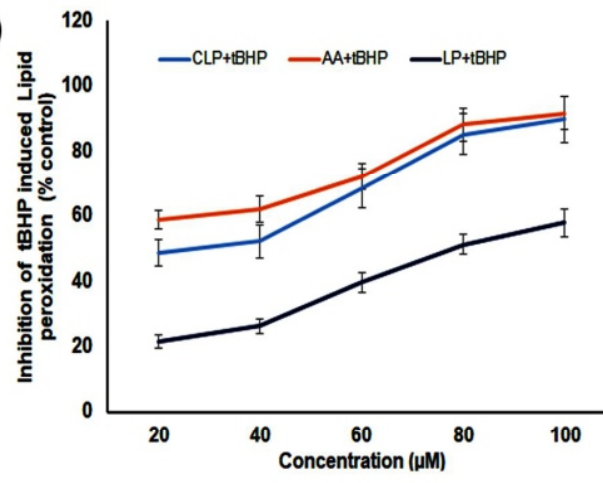

c)

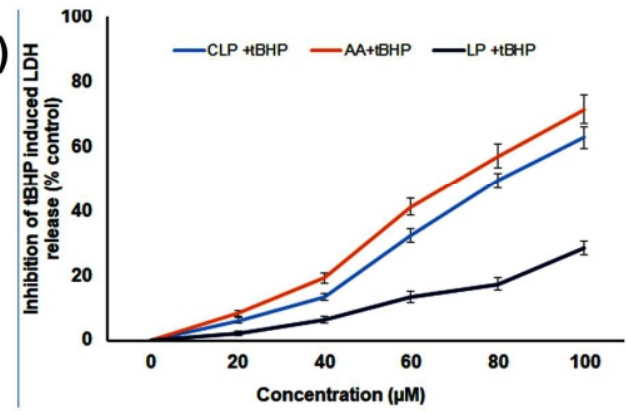

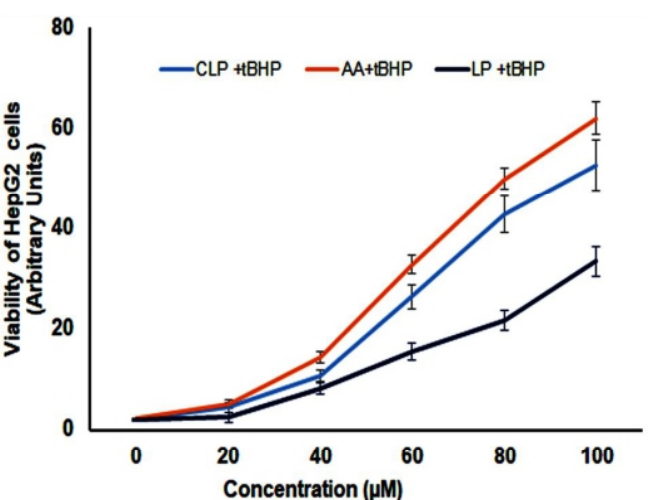

d)

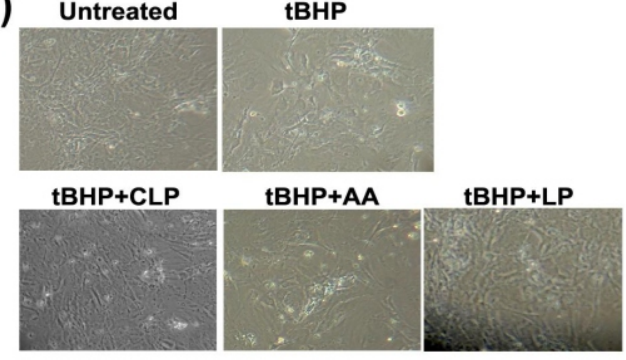

Figure 2. Protective activity of CLP against tBHP-induced cytotoxicity in MCF-12A cells.

Cells were pretreated overnight with CLP $(0,20,40,60,80$ and $100 \mu \mathrm{M})$, subsequently with tBHP $(0.25 \mathrm{mM})$ and incubated for $24 \mathrm{~h}$. Only tBHP treated cells were served as untreated control. AA and LP were used as positive control under similar concentrations. a) Protective effect of CLP on tBHP-induced lipid peroxidation in MCF-12A cells. b) Protective effect of CLP on the tBHP-induced cytotoxicity of MCF-12A cells. The results were expressed as \% viability of tBHP treated control. c) Protective effect of CLP on tBHP induced cell membrane damage. The results were expressed as \% inhibition of LDH leakage. d) Protective effect of CLP on tBHP induced morphological changes by phase-contrast microscopy. The cumulative data of each assay were obtained from 3 independent experiments and shown as means $\pm \operatorname{SEM}(n=3)$. 
Table 1. Cytoprotective effect of CLP on MCF-12A cells

\begin{tabular}{|c|c|c|c|c|c|c|c|c|c|c|}
\hline \multirow[t]{2}{*}{ No } & \multirow{2}{*}{$\begin{array}{c}\text { Concentration } \\
\qquad(\mu \mathrm{M})\end{array}$} & \multicolumn{3}{|c|}{ Inhibition of lipid peroxidation (\%) } & \multicolumn{3}{|c|}{ Cell viability (\%) } & \multicolumn{3}{|c|}{ LDH leakage (\%) } \\
\hline & & $\mathrm{CLP}+\mathrm{tBHP}$ & $\mathrm{AA}+\mathrm{tBHP}$ & $\mathrm{LP}+\mathrm{tBHP}$ & $\overline{\mathrm{CLP}+\mathrm{tBHP}}$ & $\mathrm{AA}+\mathrm{tBHP}$ & $\mathrm{LP}+\mathrm{tBHP}$ & $\mathrm{CLP}+\mathrm{tBHP}$ & $\mathrm{AA}+\mathrm{tBHP}$ & $\mathrm{LP}+\mathrm{tBHP}$ \\
\hline 1 & 20 & $48.8 \pm 3.3$ & $58.8 \pm 4.3$ & $21.6 \pm 1.9$ & $4.5 \pm 0.9$ & $5.2 \pm 0.9$ & $2.4 \pm 0.8$ & $2.4 \pm 0.8$ & $8.4 \pm 0.9$ & $2.2 \pm 0.8$ \\
\hline 2 & 40 & $52.2 \pm 4.2$ & $62.2 \pm 5.2$ & $26.2 \pm 2.1$ & $10.8 \pm 1.1$ & $14.4 \pm 1.2$ & $8.2 \pm 1.1$ & $8.2 \pm 1.1$ & $19.3 \pm 1.5$ & $6.5 \pm 1.2$ \\
\hline 3 & 60 & $68.6 \pm 4.1$ & $72.6 \pm 6.1$ & $39.6 \pm 2.9$ & $26.4 \pm 1.9$ & $32.8 \pm 2.3$ & $15.6 \pm 1.7$ & $15.6 \pm 1.7$ & $41.3 \pm 2.6$ & $13.4 \pm 1.6$ \\
\hline 4 & 80 & $85.20 \pm 5.2$ & $88.2 \pm 6.2$ & $51.2 \pm 3.1$ & $42.8 \pm 2.1$ & $49.9 \pm 3.3$ & $21.7 \pm 1.9$ & $21.7 \pm 1.9$ & $57.1 \pm 3.7$ & $17.8 \pm 2.1$ \\
\hline 5 & 100 & $89.8 \pm 5.3$ & $91.8 \pm 7.3$ & $57.8 \pm 4.1$ & $68.6 \pm 3.2$ & $74.9 \pm 4.3$ & $33.4 \pm 2.8$ & $33.4 \pm 2.8$ & $71.5 \pm 4.3$ & $28.4 \pm 2.1$ \\
\hline
\end{tabular}

Cytoprotective activity of CLP (Cyclo(L-Leu-L-Pro)) was measured in terms of inhibition of lipid peroxidation, cell viability and inhibition of LDH leakage against tBHP-induced cell damage in MCF-12A cells. AA (Ascorbic acid) and LP (L-Leucyl-L-Proline) were used as control. The results were expressed in percent of inhibition of lipid peroxidation, percent cell viability and percent of inhibition of LDH release. Each experiment was performed three times, and values were represented as mean $\pm \mathrm{SD}(\mathrm{n}+3)$

cytoprotective activities of CLP, LP or AA at different concentrations $(20-100 \mu \mathrm{M})$.

\section{Genoprotective ability of CLP on tBHP-induced DNA damage}

DNA is one of the most prominent biological targets of oxidative stress and is the most significant cancer development contributor. The CLP's genoprotective ability against tBHP-induced stress-mediated DNA damage in MCF-12A cells was determined, as shown in Figure 3a. tBHP treated cells found $44 \pm 5$ AP sites $/ 10^{5} \mathrm{bp}$, but cells treated with the CLP show fewer AP sites in concentration dependent manner. The AP sites were decreased to $12 \pm 2 \mathrm{AP}$ sites $/ 10^{5} \mathrm{bp}$ with CLP, $5 \pm 2 \mathrm{AP}$ sites/ $105 \mathrm{bp}$ with LP and $10 \pm 2 \mathrm{AP}$ sites $/ 10^{5} \mathrm{bp}$ with AA. Also, 8-OHdG, a product of oxidatively damaged DNA, was quantified by monitoring the formation of abasic sites using competitive ELISA. This assay employs an $8-\mathrm{OHdG}$-coated plate and an HRP-linked antibody to recognize oxidative stressmediated damage of DNA with high sensitivity. The results showed that $8-\mathrm{OHdG}$ concentration was significantly high in tBHP treated control $(4 \pm 0.19 \mu \mathrm{g} / \mathrm{ml})$, but its levels were decreased with CLP to $0.80 \pm 0.02, \mathrm{AA}(0.3 \pm 0.01)$ and $\mathrm{LP}(0.2 \pm 0.01) \mu \mathrm{g} / \mathrm{ml}$ in concentration dependent manner as shown in Figure $3 \mathrm{~b}$. The concentration of $8-\mathrm{OHdG}$ was significantly less with $100 \mu \mathrm{M}$ of CLP compared to tBHP treated control, indicating the DNA damage protecting activity. In vitro comet assay is a sensitive and frequently used method to confirm the genoprotective activity. ${ }^{90}$ Therefore, DNA damage protecting activity of CLP, AA and LP in tBHP treated MCF-12A cells was assessed using in vitro Comet assay, and the results
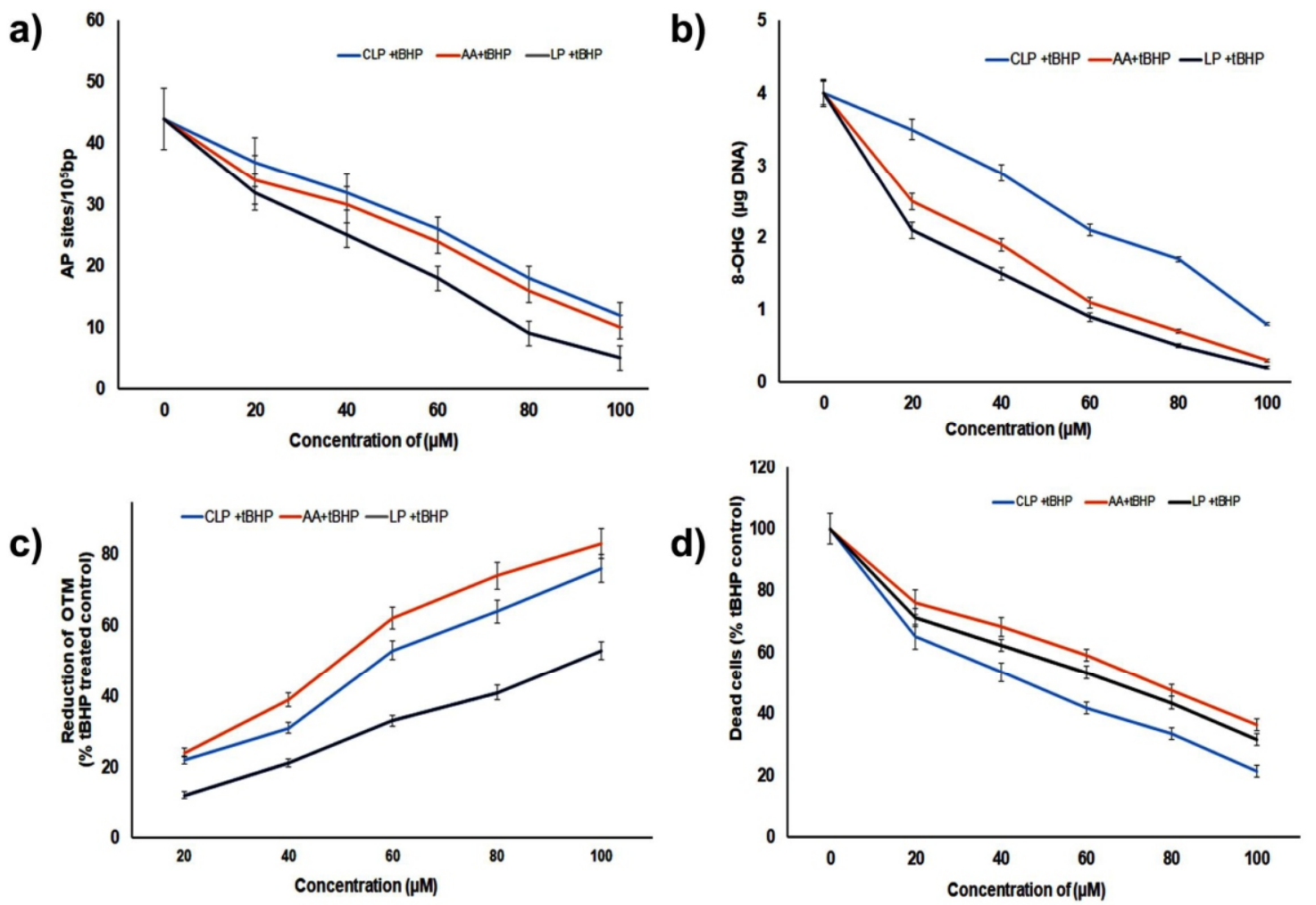

Figure 3. Genoprotective activity of CLP against tBHP-induced DNA damage in MCF-12A cells. Cells were pretreated overnight with CLP $(0,20,40,60,80$ and $100 \mu \mathrm{M})$, subsequently with tBHP $(0.25 \mathrm{mM})$ and incubated for $24 \mathrm{~h}$. AA and LP under similar conditions were used as a positive control. The genoprotective activity of CLP against tBHP-induced DNA damage in MCF-12A cells in terms of (a) Abasic (AP) sites/1x106bp, (b) 8-OHdG formation ( $\mu \mathrm{g} / \mathrm{ml})$, (c) Olive Tail Moment (\%tBHP treated control). (d) Apoptotic cell death (\%tBHP treated control) was determined by Annexin V ELISA method. The cumulative data of each assay were obtained from 3 independent experiments and shown as means $\pm \operatorname{SEM}(\mathrm{n}=3)$. 
Table 2. Genoprotective effect of CLP on MCF-12A cells

\begin{tabular}{|c|c|c|c|c|c|c|c|c|c|c|c|c|c|}
\hline \multirow[t]{2}{*}{ No } & \multirow{2}{*}{$\begin{array}{l}\text { Concentration } \\
\qquad(\mu \mathrm{M})\end{array}$} & \multicolumn{3}{|c|}{ AP sites $/ 10^{5} \mathrm{bp}$} & \multicolumn{3}{|c|}{ 8-OHdG $(\mu \mathrm{g} / \mathrm{ml})$} & \multicolumn{3}{|c|}{ Decrease in OTM $(\%)$} & \multicolumn{3}{|c|}{ Dead cells $(\%)$} \\
\hline & & $\begin{array}{l}\overline{\mathrm{CLP}+} \\
\mathrm{tBHP}\end{array}$ & $\begin{array}{l}\mathrm{AA}+ \\
\mathrm{tBHP}\end{array}$ & $\begin{array}{l}\mathrm{LP}+ \\
\mathrm{tBHP}\end{array}$ & $\begin{array}{l}\text { CLP+ } \\
\text { tBHP }\end{array}$ & $\begin{array}{l}\mathrm{AA}+ \\
\mathrm{tBHP}\end{array}$ & $\begin{array}{l}\mathrm{LP}+ \\
\mathrm{tBHP}\end{array}$ & $\begin{array}{l}\overline{\text { CLP+ }} \\
\text { tBHP }\end{array}$ & $\begin{array}{l}\mathrm{AA}+ \\
\mathrm{tBHP}\end{array}$ & $\begin{array}{l}\mathrm{LP}+ \\
\mathrm{tBHP}\end{array}$ & $\begin{array}{l}\text { CLP+ } \\
\text { tBHP }\end{array}$ & $\begin{array}{l}\mathrm{AA}+ \\
\mathrm{tBHP}\end{array}$ & $\begin{array}{l}\text { LP+ } \\
\text { BHP }\end{array}$ \\
\hline 1 & 20 & $38 \pm 4$ & $34 \pm 4$ & $32 \pm 3$ & $3.5 \pm 0.4$ & $2.5 \pm 0.11$ & $2.1 \pm 0.11$ & $22 \pm 1.8$ & $24 \pm 1.1$ & $12 \pm 0.9$ & $65.1 \pm 4.3$ & $76.2 \pm 4.1$ & $71.3 \pm 3.2$ \\
\hline 2 & 40 & $32 \pm 3$ & $30 \pm 3$ & $25 \pm 2$ & $2.9 \pm 0.1$ & $1.9 \pm 0.09$ & $1.5 \pm 0.09$ & $34 \pm 1.9$ & $39 \pm 2.4$ & $21 \pm 1.1$ & $53.6 \pm 3.2$ & $86.3 \pm 3.6$ & $62.3 \pm 3.1$ \\
\hline 3 & 60 & $26 \pm 2$ & $24 \pm 2$ & $18 \pm 2$ & $2.1 \pm 0.1$ & $1.1 \pm 0.06$ & $0.9 \pm 0.02$ & $53 \pm 2.7$ & $62 \pm 2.8$ & $33 \pm 1.4$ & $41.8 \pm 2.1$ & $59.2 \pm 3.2$ & $53.5 \pm 2.9$ \\
\hline 4 & 80 & $18 \pm 2$ & $16 \pm 2$ & $9 \pm 2$ & $1.7 \pm 0.03$ & $0.7 \pm 0.03$ & $0.5 \pm 0.01$ & $64 \pm 2.8$ & $74 \pm 2.9$ & $41 \pm 2.1$ & $33.4 \pm 2.1$ & $47.5 \pm 3.1$ & $43.5 \pm 1.8$ \\
\hline 5 & 100 & $12 \pm 2$ & $10 \pm 2$ & $5 \pm 2$ & $0.80 \pm 0.02$ & $0.3 \pm 0.01$ & $0.2 \pm 0.01$ & $76 \pm 3.3$ & $83 \pm 3.1$ & $53 \pm 2.9$ & $21.2 \pm 1.9$ & $36.3 \pm 2.2$ & $31.6 \pm 1.6$ \\
\hline
\end{tabular}

were expressed as the Olive Tail Moment (OTM) as shown in Figure 3c. The OTM was increased by $80 \%$ in MCF-12A cells treated with tBHP compared to the negative control. However, CLP decreased the tBHPinduced OTM to $3 \pm 2.9 \%$ compared to $\mathrm{tBHP}$ positive control. Finally, DNA damage protecting activity of CLP, AA, and LP was confirmed by Annexin V assay in tBHP treated MCF-12A cells (Figure 3d).

a)

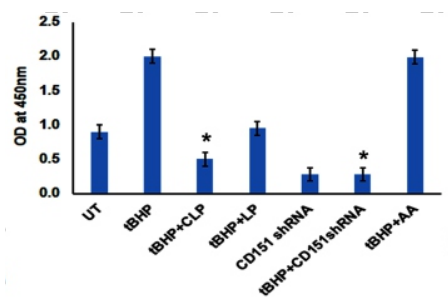

c)

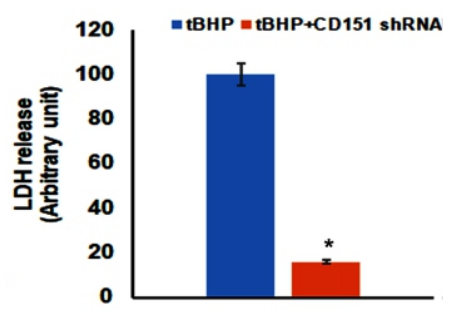

e)

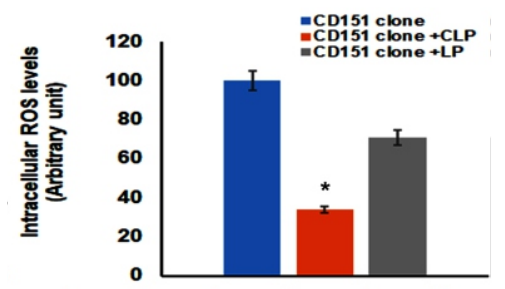

g)

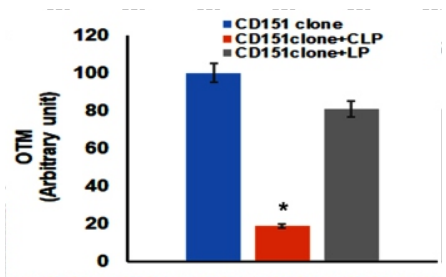

The results showed that the number of dead cells decreased with CLP was $31.6 \pm 1.6 \%$ and with positive controls AA $(36.3 \pm 2.2 \%)$ and LP $(31.6 \pm 1.6 \%)$, respectively with an increase in concentration to 100 $\mu \mathrm{M}$ compared to tBHP control, which is considered as $100 \%$. Table 2 lists the data of genoprotective effect of CLP, LP or AA in MCF-12A cells.

b)

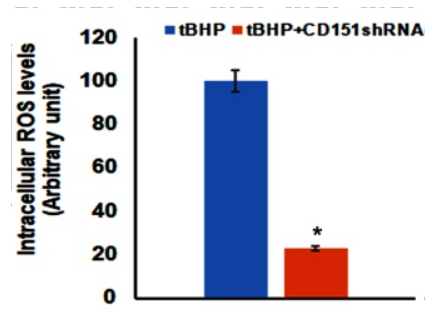

d)

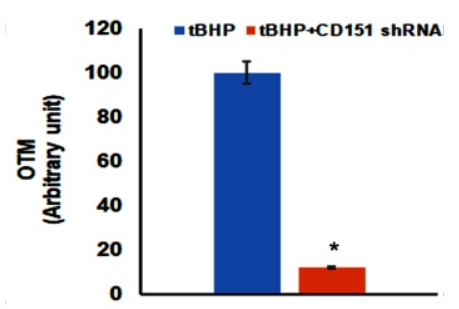

f)

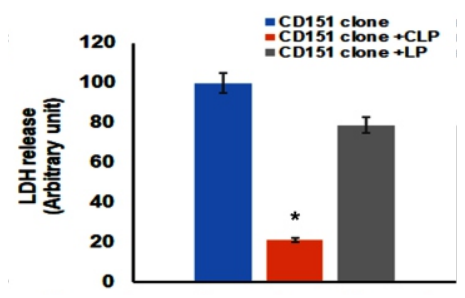

Figure 4. CLP protects tHBP treated MCF-12A cells by targeting CD151.

tBHP-induced CD151 levels were reduced with CLP and CD151shRNA(a). MCF-12A cells were pretreated overnight with CLP (70.6 $\mu \mathrm{M})$ and ascorbic acid $(60.5 \mu \mathrm{M})$ or transfected with CD151shRNA, subsequently with tBHP $(0.25 \mathrm{mM})$ and incubated for $24 \mathrm{~h}$. Untreated cells were served as control. The expression of CD151 was determined by cell-based ELISA assay. The results were expressed in OD at 450nm. After silencing the CD151 gene using shRNA, the intracellular ROS (b), extracellular LDH levels (c) and OTM (d) were evaluated in tBHP treated MCF-12A cells. Means \pm SEM ( $n=3), p<0.05$. MCF-12A cells $(5 \times 104)$ in a 6-well plate were transfected with $10 \mu \mathrm{g}$ untagged Precision Shuttle mammalian plasmid encoding CD151 using Turbo Fectin Transfection Reagent. After $24 \mathrm{~h}$ of transfection, cells were treated with CLP or LP for 24h. The intracellular ROS was measured using DCF-DA by cellular ROS detection assay kit (e), extracellular LDH using LDH assay kit (f) and DNA damage by alkaline comet assay (g) as described above. The cumulative data of each assay were obtained from 3 independent experiments, and results were shown as means \pm SEM $(\mathrm{n}=3),{ }^{*} \mathrm{p}<0.05$ 
a)

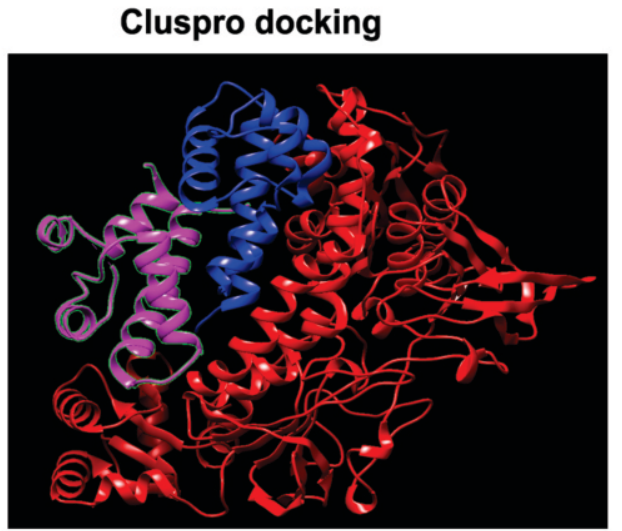

c)

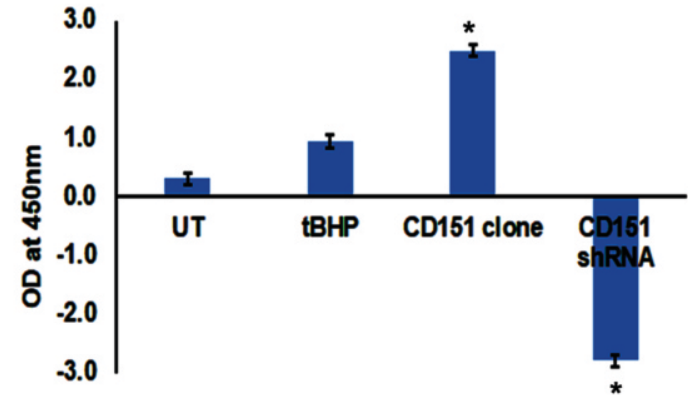

b)

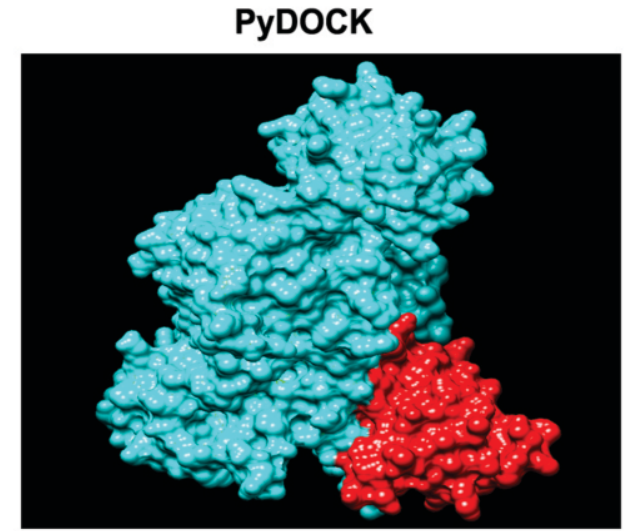

d)

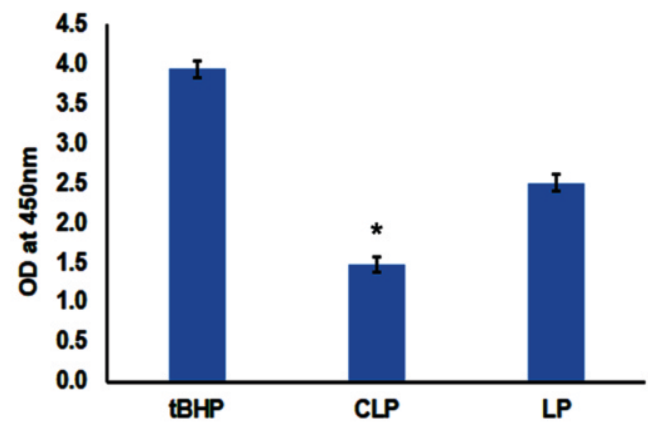

Figure 5. In Silico interaction of CD151 with P450.

a) In silico docking of CD151 (receptor) with P450 (ligand) was performed using ClusPro web server. The receptor and ligand were represented as ribbon form. The binding energy of CD151 with P450 was calculated as $-990 \mathrm{kcal} / \mathrm{mol}$. b) In silico docking of CD151 (receptor) with P450 (ligand) was performed using PyDOCK webserver. The receptor and ligand were represented as a solid model. The binding energy of CD151 with P450 was calculated as $-38.3 \mathrm{kcal} / \mathrm{mol}$. c) The impact of tBHP, CD151 shRNA and CD151 clone on cytochrome p450 levels was determined using quantitative sandwich ELISA. d) Effect of CLP and LP on tBHP-induced cytochrome p450 levels. The cumulative data of each assay were obtained from 3 independent experiments, and results were shown as means \pm SEM $(\mathrm{n}=3),{ }^{*} \mathrm{p}<0.05$

Pathway analysis of CD151 mediated t-BHP induced cytotoxicity

Kučera et al. reported that t-BHP is metabolized by cytochrome P450 and glutathione peroxidase mediated pathways. ${ }^{5} \mathrm{CD} 151$-dependent tetraspaninenriched microdomains (TEM) correlated with hepatocarcinoma. ${ }^{91}$ Previously, we showed that CLP reduced the CD151 expression and its interaction with EGFR. ${ }^{17}$ In the current study, we found that tBHP stimulated a 10-fold increase in the expression of CD151 compared to untreated control in MCF$12 \mathrm{~A}$ cells. However, CLP and LP treatment reduced the $4.0(p>0.05)$ and 2.1-folds of tBHP-induced expression of CD151, respectively, and CD151shRNA treatment 7.1-folds $(\mathrm{p}>0.05)$ in MCF$12 \mathrm{~A}$ cells (Figure $4 \mathrm{a}$ ), but AA did not affect the CD151 expression (Data not shown). CD151 gene silencing using shRNA reduced the intracellular ROS (4.3-folds) (Figure 4b), extracellular LDH levels (6.2-folds) (Figure 4c), and OTM (8.3-folds) (Figure 4d) in tBHP treated MCF-12A cells. Further, CLP and LP treatment reduced the intracellular ROS levels 2.9 and 1.4-folds, respectively (Figure 4e), LDH levels 4.7 and 1.3-folds, respectively (Figure 4f) and OTM levels 5.2 and 1.2-folds, respectively (Figure 4g) in CD151 overexpressed MCF-12A cells, indicating that CLP protects the MCF-12A cells by targeting Cd151.

Protein-protein interactions are important for understanding cellular function and organization. To find the downstream mediator of CD151 in tHBPinduced cytotoxicity, we analyzed the interaction between CD151 and cytochrome P450, which is an important mediator of tBHP metabolism and membrane damage. By using Cluspro docking method, we interpreted that CD151 interacts with cytochrome P450 strongly (Figure 5a) with docking score of $-993 \mathrm{k} \mathrm{cal} / \mathrm{mol}$. We have verified the results using another docking study, PyDOCK webserver (Figure 5b). The docking score of CD151 with P450 was $-38.39 \mathrm{k} \mathrm{cal} / \mathrm{mol}$. Thus, P450 shows a high binding tendency for CD151 protein.

To further focus our investigation on the protection exerted by CLP in CD151 mediated cytotoxicity in tBHP treated MCF-12A cells, we determined the cytochrome $\mathrm{p} 450$ levels in MCF-12A cells treated with tBHP, CD151 shRNA and CD151 clone using quantitative sandwich ELISA (Figure $5 \mathrm{c})$. The results showed that CD151 clone enhanced the cytochrome P450 levels by 8-folds, and CD151 shRNA reduced the cytochrome P450 levels by 9folds. However, tBHP-induced cytochrome P450 levels by only 3 -folds. Further, treatment with CLP and LP significantly reduced the tBHP-induced 
cytochrome P450 levels (Figure 5d), but not considerably by AA (Data Not shown). These results indicate that $\mathrm{CD} 151$ is an upstream mediator of tBHP-induced cytotoxicity in MCF-12A cells.

\section{Discussion}

In normal physiological conditions, the homeostasis of ROS is maintained by cellular antioxidant defense system but during oxidative stress this homeostasis is lost which causes disturbance in the metabolism of free radicals and their detoxification. ${ }^{92}$ Excessive generation of radicals causes oxidative damage in proteins, fatty acids, and DNA which leads to inflammation and cancer. The stimulation of the antiradical mechanism is one of the most significant determinants of cytoprotective ability against oxidative stressinduced diseases. ${ }^{93}$

CLP is a biologically active homodetic cyclic peptide, which we reported to exhibit significant inhibition of tBHP-induced oxidative stress in MCF$12 \mathrm{~A}$ cell line. CLP's scavenging potential against intracellular ROS and mitochondrial superoxide and hydroxyl radicals was comparable to that of Ascorbic acid, a well-known antioxidant. This study emphasizes the significant cytoprotective as well as genoprotective activity of the CLP against tBHPinduced cellular stress in MCF-12A cells and results were compared to linear dipeptide (LP). Previously, a large amount of data pertaining to dipeptides, including aspartame (L-aspartyl-L-phenylalanine methyl ester) as well as L-alanyl-L-glutamine as cytoprotective agents was documented. ${ }^{94}$ Kaul et al. provided evidence suggesting that proline (Pro) has the ability to scavenge free radicals in vitro. ${ }^{95}$ Besides the role of proline as antioxidant, ameliorating metal toxicity has also been reported recently. ${ }^{96,97}$ Research by Phang et al. emphasized proline as a "stress substrate" and suggested it as a potential anti-cancer agent. ${ }^{98}$ Also, Pro has wound healing potential. ${ }^{99}$ In addition, Pro was reported as an activator of mTOR signal pathway in concert with leucine. ${ }^{100}$

Cyclic dipeptides can bind to diverse targets due to conformationally constrained scaffolds and a vast number of tailoring enzymes. ${ }^{101}$ Yan et al. reported that hydrophobic amino acids and proline are critical for cyclic dipeptides' biological activity. ${ }^{102}$ The peptide bonds in proteins normally have a planar trans configuration. However, due to neighboring substituents' steric requirements, the cis form is more stable than the trans form when the Pro (imino acid) occurs at the bond's carboxyl-terminal side. ${ }^{103}$ Further, the Pro ring's restricted mobility might be related to cyclic dipeptides. ${ }^{104}$ The cis-trans isomerism of the $\mathrm{N}$-alkyl amide bond in the Pro was found to be involved in receptor-mediated biological activity. ${ }^{55}$ The connection between the configuration of Pro and its physical activity might be important in explaining the mechanism of the inhibitory activity of cyclodipeptides.

Because of these properties, cyclic dipeptides consist of hydrophobic amino acids like leucine, and terminal amino acid proline are products of rational drug design. CLP significantly improved the viability of tBHP treated MCF-12A cells in a concentration-dependent manner. Further, CLP's cytoprotective effect in tBHP-induced cellular leakage of LDH was significantly high compared to other dipeptides like $\beta$-alanine-histidine and carnosine. ${ }^{105}$ Besides, pretreatment with CLP protected MCF-12A cells from tBHP-induced morphological changes better than LP. These results indicate the efficacy of marine natural product, the CLP as a cytoprotective agent.

Later, we studied CLP's effect on genoprotective activity against tBHP-induced stress in MCF-12A cell line. The results showed that CLP exhibited remarkable protection against DNA damage in terms of levels of 8-OHdG and tailing in comet assay. Limited reports are available on genoprotective activity of dipeptide. Thus, we have made an attempt to study the effect of CLP as a cytoprotective and genoprotective agent against stress-induced model. The present study showed that CLP is an efficient dipeptide, which can regulate cytoprotective cellular mechanism in addition to providing protection to DNA damage caused by oxidative stress.

Apart from metastatic activity, CD151dependent TEM mediates hepatocarcinoma ${ }^{91}$ and liver fibrosis ${ }^{106}$, and has also been proposed as CD151 potential therapeutic target of liver fibrosis. ${ }^{107} \mathrm{CD} 151$ is a membrane protein that transduces intracellular signaling and regulates cellular functions. Previously, we showed that CLP reduced the CD151 expression and its interaction with EGFR. ${ }^{17}$ Bae et al. demonstrated that EGF induces $\mathrm{H}_{2} \mathrm{O}_{2}$ generation via EGFR in cancer cell lines. ${ }^{108}$ The present study observed increased levels of CD151 in tBHP treated MCF-12A cells. However, tBHP-induced CD151 levels were reduced with CD151shRNA and CLP treatment which are comparable. However, LP did not affect CD151 expression. In addition, CD151 gene silencing decreased the tHBP- induced ROS and LDH levels in tHBP treated MCF-12A cells, indicating the involvement of CD151 in tHBP- induced cytotoxicity. In addition, CD151 gene silencing reduced the tHBP induced OTM in MCF-12A cells. Further, CLP reduced the intracellular ROS, extracellular LDH levels, and genotoxicity (OTM) in CD151 overexpressed MCF-12A cells.

High docking score in the interaction study of CD151 with cytochrome P450 by Cluspro docking method and PyDOCK web server indicated strong interaction CD151 with cytochrome P450. Further, overexpression of CD151 increased the CYP levels but reduced with CD151 shRNA with a moderate increase with tBHP. Also, treatment with CLP and 
LP significantly reduced the tBHP induced cytochrome P450 levels, but not AA. Additionally, CD151 gene silencing using CD151 shRNA reduced the cytochrome P450 levels in ABHP-induced MCF$12 \mathrm{~A}$ cells. These results indicate that CD151 is an upstream mediator of tBHP-induced cytotoxicity in MCF-12A cells and CLP protecting the MCF-12A cells by targeting Cd151.

In the present study, we have reported the cytoprotective role of CLP against various ROS types using MCF-12A cell line model. CLP increases the cellular antioxidant status in MCF-12A cells and scavenges the tBHP-induced intracellular ROS levels. This study also observed that the CLP protected MCF-12A cells from tBHP-induced lipid peroxidation, $\mathrm{LDH}$ leakage, and morphological changes. Moreover, a significant genoprotective activity of the CLP was observed against tBHPinduced DNA damage in MCF-12A cell line compared to positive control LP. Furthermore, CLP also reduced the tBHP-induced DNA damage by decreasing AP sites, 8-OHdG levels, and OTM in a concentration-dependent manner. There was a significant effect of CLP on expression of CD151 which can be compared to CD151 shRNA mediated gene silencing. Protein-protein interaction study by Cluspro docking method and PyDOCK web server indicated strong interaction CD151 with cytochrome P450. An increase in cytochrome P450 levels with CD151 overexpression and reduction with CD151 gene silencing by shRNA, as well as reduction with CLP and LP, indicates the involvement of CD151 gene via cytochrome $\mathrm{P} 450$ in tBHP-induced cytotoxicity in MCF-12A cells. These results also suggest that CLP protects the MCF-12A cells more significantly by targeting CD151 compared to its linear counterpart, LP. In conclusion, based on the intracellular ROS scavenging ability, cytoprotective, and genoprotective activities, CLP can be used as an efficient agent against oxidative damage mediated pathological diseases like cancer and inflammation.

\section{Funding}

The corresponding author, Prof. RamaRao Malla (Receiver of the grant) thanks CSIR, New Delhi, India (File No: 37(1683)/17/EMR-II) dated: 05.05.2017) for providing funding to carry out this work.

\section{Acknowledgement}

The authors also thank GITAM University for providing lab facilities. The authors also thank Prof. Raja P. Pappu, Director, Research Consultancy, GITAM for proofreading of syntax and grammatical errors.

\section{Ethical statements}

None.

\section{Conflict of Interest}

Authors declare no potential conflicts of interest.

\section{References}

1. Cortes DF, Sha W, Hower V, Blekherman G, Laubenbacher R, Akman S, et al. Differential gene expression in normal and transformed human mammary epithelial cells in response to oxidative stress. Free Radic Biol Med. 2011;50(11):1565-74.

2. Zhao W, Feng H, Sun W, Liu K, Lu J-J, Chen X. Tert-butyl hydroperoxide (t-BHP) induced apoptosis and necroptosis in endothelial cells: Roles of NOX4 and mitochondrion. Redox biology. 2017;11:524-34.

3. Kucera O, Endlicher R, Rousar T, Lotkova H, Garnol T, Drahota Z, et al. The effect of tert-butyl hydroperoxide-induced oxidative stress on lean and steatotic rat hepatocytes in vitro. Oxidative medicine and cellular longevity. 2014;2014: 752506.

4. Ewald CY, Hourihan JM, Blackwell TK. Oxidative Stress Assays (arsenite and tBHP) in Caenorhabditis elegans. Bio-protocol. 2017;7(13):pii: e2365.

5. Kučera $\mathrm{O}$, Endlicher R, Roušar T, Lotková $H$, Garnol T, Drahota Z, et al. The effect of tert-butyl hydroperoxide-induced oxidative stress on lean and steatotic rat hepatocytes in vitro. Oxidative medicine and cellular longevity. 2014;2014: 752506.

6. Kaur P, Kaur G, Bansal MP. Tertiary-butyl hydroperoxide induced oxidative stress and male reproductive activity in mice: role of transcription factor NF-kappaB and testicular antioxidant enzymes. Reprod Toxicol. 2006; 22(3):479-84.

7. Chen HH, Wang TC, Lee YC, Shen PT, Chang JY, Yeh TK, et al. Novel Nrf2/ARE activator, transConiferylaldehyde, induces a HO-1-mediated defense mechanism through a dual p38 $\alpha$ /MAPKAPK-2 and PK-N3 signaling pathway. Chem Res Toxicol. 2015;28(9):1681-92.

8. Taffe BG, Takahashi N, Kensler TW, Mason RP. Generation of free radicals from organic hydroperoxide tumor promoters in isolated mouse keratinocytes. Formation of alkyl and alkoxyl radicals from tert-butyl hydroperoxide and cumene hydroperoxide. J Biol Chem. 1987;262(25):12143-9.

9. Guyton KZ, Thompson JA, Kensler TW. Role of quinone methide in the in vitro toxicity of the skin tumor promoter butylated hydroxytoluene hydroperoxide. Chem Res Toxicol. 1993;6(5):731-8.

10. Müehlematter D, Ochi T, Cerutti P. Effects of tert-butyl hydroperoxide on promotable and non-promotable JB6 mouse epidermal cells. Chem Biol Interact. 1989;71(4):339-52. 
11. Giordani A, Haigle J, Leflon P, Risler A, Salmon $\mathrm{S}$, Aubailly $\mathrm{M}$, et al. Contrasting effects of excess ferritin expression on the iron-mediated oxidative stress induced by tert-butyl hydroperoxide or ultraviolet-A in human fibroblasts and keratinocytes. J Photochem Photobiol B. 2000;54(1):43-54.

12. Kulak MV, Cyr AR, Woodfield GW, Bogachek M, Spanheimer PM, Li T, et al. Transcriptional regulation of the GPX1 gene by TFAP2C and aberrant $\mathrm{CpG}$ methylation in human breast cancer. Oncogene. 2013;32(34):4043-51.

13. Thompson JA, Bolton JL, Malkinson AM. Relationship between the metabolism of butylated hydroxytoluene (BHT) and lung tumor promotion in mice. Exp Lung Res. 1991;17(2): 439-53.

14. Lapshina E, Zavodnik I, Labieniec-Watala M, Rekawiecka K, Bryszewska M. Cytotoxic and genotoxic effects of tert-butyl hydroperoxide on Chinese hamster B14 cells. Mutation research. 2005;583:189-97.

15. +Seo GS, Jiang WY, Park PH, Sohn DH, Cheon JH, Lee SH. Hirsutenone reduces deterioration of tight junction proteins through EGFR/Akt and ERK1/2 pathway both converging to $\mathrm{HO}-1$ induction. Biochem Pharmacol. 2014;90(2):115-25.

16. Huang RP, Peng A, Golard A, Hossain MZ, Huang R, Liu YG, et al. Hydrogen peroxide promotes transformation of rat liver nonneoplastic epithelial cells through activation of epidermal growth factor receptor. Mol Carcinog. 2001;30(4):209-17.

17. Kgk D, Kumari S, G S, Malla RR. Marine natural compound cyclo(L-leucyl-L-prolyl) peptide inhibits migration of triple negative breast cancer cells by disrupting interaction of CD151 and EGFR signaling. Chem Biol Interact. 2020;315:108872.

18. Nankivell P, Williams H, McConkey C, Webster K, High A, MacLennan K, et al. Tetraspanins CD9 and CD151, epidermal growth factor receptor and cyclooxygenase-2 expression predict malignant progression in oral epithelial dysplasia. British journal of cancer. 2013;109(11):2864-74.

19. Moribe H, Konakawa R, Koga D, Ushiki T, Nakamura K, Mekada E. Tetraspanin is required for generation of reactive oxygen species by the dual oxidase system in Caenorhabditis elegans. PLoS genetics. 2012;8(9):e1002957.

20. DeYulia GJ, Jr., Cárcamo JM. EGF receptorligand interaction generates extracellular hydrogen peroxide that inhibits EGFR-associated protein tyrosine phosphatases. Biochemical and biophysical research communications. 2005;334(1):38-42.

21. Moribe H, Mekada E. Co-occurrence of tetraspanin and ROS generators: Conservation in protein cross-linking and other developmental processes. Worm. 2013;2(2):e23415.

22.Mani B, Agarwal M, Katiyar-Agarwal S. Comprehensive Expression Profiling of Rice Tetraspanin Genes Reveals Diverse Roles During Development and Abiotic Stress. Frontiers in Plant Science. 2015;6(1088).

23. Wang L, Huang Z, Huang W, Chen X, Shan P, Zhong $\mathrm{P}$, et al. Inhibition of epidermal growth factor receptor attenuates atherosclerosis via decreasing inflammation and oxidative stress. Scientific Reports. 2017;7(1):45917.

24. Chen TC, Sakaki T, Yamamoto K, Kittaka A. The roles of cytochrome P450 enzymes in prostate cancer development and treatment. Anticancer Res. 2012;32(1):291-8.

25.McFadyen MC, Melvin WT, Murray GI. Cytochrome P450 enzymes: novel options for cancer therapeutics. Mol Cancer Ther. 2004;3(3):363-71.

26. Ranjit S, Midde NM, Sinha N, Patters BJ, Rahman MA, Cory TJ, et al. Effect of Polyaryl Hydrocarbons on Cytotoxicity in Monocytic Cells: Potential Role of Cytochromes P450 and Oxidative Stress Pathways. PLoS One. 2016;11(9):e0163827.

27. Yang XJ, Lu HY, Li ZY, Bian Q, Qiu LL, Li Z, et al. Cytochrome P450 2A13 mediates aflatoxin B1-induced cytotoxicity and apoptosis in human bronchial epithelial cells. Toxicology. 2012;300(3):138-48.

28. Liu H, Baliga M, Baliga R. Effect of cytochrome P450 2E1 inhibitors on cisplatin-induced cytotoxicity to renal proximal tubular epithelial cells. Anticancer Res. 2002;22(2a):863-8.

29. Donatus IA, Sardjoko, Vermeulen NP. Cytotoxic and cytoprotective activities of curcumin. Effects on paracetamol-induced cytotoxicity, lipid peroxidation and glutathione depletion in rat hepatocytes. Biochem Pharmacol. 1990;39(12):1869-75.

30. Chen Q, Cederbaum AI. Cytotoxicity and apoptosis produced by cytochrome P450 2E1 in Hep G2 cells. Mol Pharmacol. 1998;53(4):638-48.

31. Caro AA, Cederbaum AI. Role of cytochrome P450 in phospholipase A2- and arachidonic acid-mediated cytotoxicity. Free Radic Biol Med. 2006;40(3):364-75.

32. Manikandan P, Nagini S. Cytochrome P450 Structure, Function and Clinical Significance: A Review. Curr Drug Targets. 2018;19(1):38-54.

33. Ye W, Chen R, Chen X, Huang B, Lin R, Xie X, et al. AhR regulates the expression of human cytochrome P450 1A1 (CYP1A1) by recruiting Sp1.Febs j. 2019;286(21):4215-31.

34. Morishima Y, Peng HM, Lin HL, Hollenberg PF, Sunahara RK, Osawa Y, et al. Regulation of cytochrome P450 2E1 by heat shock protein 90- 
dependent stabilization and CHIP-dependent proteasomal degradation. Biochemistry. 2005;44(49):16333-40.

35. Karthikeyan BS, Akbarsha MA, Parthasarathy S. Network analysis and cross species comparison of protein-protein interaction networks of human, mouse and rat cytochrome $\mathrm{P} 450$ proteins that degrade xenobiotics. Mol Biosyst. 2016;12(7):2119-34.

36. Praporski S, Ng SM, Nguyen AD, Corbin CJ, Mechler A, Zheng J, et al. Organization of cytochrome P450 enzymes involved in sex steroid synthesis. J Biol Chem. 2009;284(48):33224-32.

37. Zhang YJ, Gan RY, Li S, Zhou Y, Li AN, Xu DP, et al. Antioxidant Phytochemicals for the Prevention and Treatment of Chronic Diseases. Molecules (Basel, Switzerland). 2015;20(12): 21138-56.

38. Chakraborty K, Joy M, Chakkalakal SJ. Antioxidant and antiinflammatory secondary metabolites from the Asian green mussel Perna viridis. Journal of food biochemistry. 2019;43(3):e12736.

39. Abdelfattah MS, Elmallah MIY, Ebrahim HY, Almeer RS, Eltanany RMA, Abdel Moneim AE. Prodigiosins from a marine sponge-associated actinomycete attenuate $\mathrm{HCl} /$ ethanol-induced gastric lesion via antioxidant and antiinflammatory mechanisms. PLoS One. 2019;14(6): 0216737.

40. Li X, Xia Z, Tang J, Wu J, Tong J, Li M, et al. Identification and Biological Evaluation of Secondary Metabolites from Marine Derived Fungi-Aspergillus sp. SCSIOW3, Cultivated in the Presence of Epigenetic Modifying Agents. Molecules (Basel, Switzerland). 2017;22(8).

41. Fuentes-Tristan S, Parra-Saldivar R, Iqbal HMN, Carrillo-Nieves D. Bioinspired biomolecules: Mycosporine-like amino acids and scytonemin from Lyngbya sp. with UV-protection potentialities. J Photochem Photobiol B. 2019;201:111684.

42. Subramani R, Aalbersberg W. Marine actinomycetes: an ongoing source of novel bioactive metabolites. Microbiological research. 2012;167(10):571-80.

43.Kang HK, Choi MC, Seo CH, Park Y. Therapeutic Properties and Biological Benefits of Marine-Derived Anticancer Peptides. International journal of molecular sciences. 2018;19(3).

44. Prasad C. Bioactive cyclic dipeptides. Peptides. 1995;16(1):151-64.

45. Martinez-Luis S, Gomez JF, Spadafora C, Guzman HM, Gutierrez M. Antitrypanosomal alkaloids from the marine bacterium Bacillus pumilus. Molecules (Basel, Switzerland). 2012;17(9):11146-55.

46. Li X, Dobretsov S, Xu Y, Xiao X, Hung OS, Qian
PY.Antifouling diketopiperazines produced by a deep-sea bacterium, Streptomyces fungicidicus. Biofouling. 2006;22(3-4):201-8.

47. Wang N, Cui C-B, Li C-W. A new cyclic dipeptide penicimutide: the activated production of cyclic dipeptides by introduction of neomycinresistance in the marine-derived fungus Penicilliumpurpurogenum G59. Archives of pharmacal research. 2016;39(6):762-70.

48. Ahmed EF, Hassan HM, Rateb ME, AbdelWahab N, Sameer S, Aly Taie HA, et al. A Comparative biochemical study on two marine endophytes, Bacterium SRCnm and Bacillus sp. JS, Isolated from red sea algae. Pakistan journal of pharmaceutical sciences. 2016;29(1):17-26.

49. Visamsetti A, Ramachandran SS, Kandasamy D. Penicillium chrysogenum DSOA associated with marine sponge (Tedania anhelans) exhibit antimycobacterial activity. Microbiological research. 2016;185:55-60.

50. Dong Y, Cui CB, Li CW, Hua W, Wu CJ, Zhu TJ, et al. Activation of dormant secondary metabolite production by introducing neomycin resistance into the deep-sea fungus, Aspergillus versicolor ZBY-3. Marine drugs. 2014;12(8):4326-52.

51. Magnusson J, Schnurer J. Lactobacillus coryniformis subsp. coryniformis strain $\mathrm{Si} 3$ produces a broad-spectrum proteinaceous antifungal compound. Applied and environmental microbiology. 2001;67(1):1-5.

52. Houston DR, Synstad B, Eijsink VG, Stark MJ, Eggleston IM, van Aalten DM. Structure-based exploration of cyclic dipeptide chitinase inhibitors. Journal of medicinal chemistry. 2004;47(23):5713-20.

53. Nicholson B, Lloyd GK, Miller BR, Palladino MA, Kiso Y, Hayashi Y, et al. NPI-2358 is a tubulin-depolymerizing agent: in-vitro evidence for activity as a tumor vascular-disrupting agent. Anti-cancer drugs. 2006;17(1):25-31.

54. Sinha S, Srivastava R, De Clercq E, Singh RK. Synthesis and antiviral properties of arabino and ribonucleosides of 1,3-dideazaadenine, 4-nitro1,3-dideazapurine and diketopiperazine. Nucleosides, nucleotides \& nucleic acids. 2004;23(12):1815-24.

55. Graz M, Hunt A, Jamie H, Grant G, Milne P. Antimicrobial activity of selected cyclic dipeptides. Die Pharmazie. 1999;54(10):772-5.

56. Kwon OS, Park SH, Yun BS, Pyun YR, Kim CJ. Cyclo(dehydroala-L-Leu), an alpha-glucosidase inhibitor from Penicillium sp. F70614. The Journal of antibiotics. 2000;53(9):954-8.

57. Nishanth Kumar S, Dileep C, Mohandas C, Nambisan B, Ca J. Cyclo(D-Tyr-D-Phe): a new antibacterial, anticancer, and antioxidant cyclic dipeptide from Bacillus sp. N strain associated with a rhabditid entomopathogenic nematode. Journal of peptide science. 2014;20(3):173-85. 
58. Koo KB, Suh HJ, Ra KS, Choi JW. Protective effect of cyclo(his-pro) on streptozotocininduced cytotoxicity and apoptosis in vitro. Journal of microbiology and biotechnology. 2011;21(2):218-27.

59. Tezgel Ö, Puchelle V, Du H, Illy N, Guégan P. Modification of proline-based 2, 5-diketopiperazines by anionic ring-opening polymerization. Journal of Polymer Science Part A: Polymer Chemistry. 2019;57(9):1008-16.

60.Nilov DK, Yashina KI, Gushchina IV, Zakharenko AL, Sukhanova MV, Lavrik OI, et al. 2,5-Diketopiperazines: A New Class of Poly(ADP-ribose)polymerase Inhibitors. Biochemistry Biokhimiia. 2018;83(2):152-8.

61. Nagaseshu P, Gayatridevi V, Kumar A, Kumari S, Mohan M, Malla R. Antioxidant and antiproliferative potentials of marine actinomycetes. Int J Pharm Pharm Sci. 2016;8:277-84.

62. Pudi N, Varikuti GD, Badana AK, Gavara MM, Kumari S, Malla RJJAPS. Studies on optimization of growth parameters for enhanced production of antibiotic alkaloids by isolated marine actinomycetes. Journal of Applied Pharmaceutical Science. 2016;6(10):181-8.

63. Rhee KH. Isolation and characterization of Streptomyces sp KH-614 producing anti-VRE (vancomycin-resistant enterococci) antibiotics. The Journal of general and applied microbiology. 2002;48(6):321-7.

64. Su J, Zhong Y, Zeng L, Wu H, Shen X, Ma K. A new $\mathrm{N}$-carboxyindole alkaloid from the marine sponge Rhaphisia pallida. Journal of natural products. 1996;59(5):504-6.

65. Yang L, Tan R-x, Wang Q, Huang W-y, Yin Y-x. Antifungal cyclopeptides from Halobacillus litoralis YS3106 of marine origin. Tetrahedron letters. 2002;43(37):6545-8.

66. Santos OC, Soares AR, Machado FL, Romanos MT, Muricy G, Giambiagi-deMarval M, et al. Investigation of biotechnological potential of sponge-associated bacteria collected in Brazilian coast. Letters in applied microbiology. 2015;60(2):140-7.

67. Ser HL, Palanisamy UD, Yin WF, Abd Malek $\mathrm{SN}$, Chan KG, Goh BH, et al. Presence of antioxidative agent, Pyrrolo[1,2-a]pyrazine-1,4dione, hexahydro- in newly isolated Streptomyces mangrovisoli sp. nov. Frontiers in microbiology. 2015;6:854.

68. Tan LT, Ser HL, Yin WF, Chan KG, Lee LH, Goh $\mathrm{BH}$. Investigation of Antioxidative and Anticancer Potentials of Streptomyces sp. MUM256 Isolated from Malaysia Mangrove Soil. Frontiers in microbiology. 2015;6:1316.

69. Alshaibani M, Zin N, Jalil J, Sidik N, Ahmad SJ, Kamal N, et al. Isolation, Purification, and Characterization of Five Active Diketopiperazine Derivatives from Endophytic Streptomyces SUK
25 with Antimicrobial and Cytotoxic Activities. Journal of microbiology and biotechnology. 2017;27(7):1249-56.

70. Rhee KH. Cyclic dipeptides exhibit synergistic, broad spectrum antimicrobial effects and have anti-mutagenic properties. International journal of antimicrobial agents. 2004;24(5):423-7.

71. Gowrishankar S, Poornima B, Pandian SK. Inhibitory efficacy of cyclo(L-leucyl-L-prolyl) from mangrove rhizosphere bacterium-Bacillus amyloliquefaciens (MMS-50) toward cariogenic properties of Streptococcus mutans. Res Microbiol. 2014;165(4):278-89.

72. Kgk D, Kumari S, G S, Malla RR. Marine natural compound cyclo(L-leucyl-L-prolyl) peptide inhibits migration of triple negative breast cancer cells by disrupting interaction of CD151 and EGFR signaling. Chemico-biological interactions. 2019;315:108872.

73. Rao Malla R, Raghu H, Rao JS. Regulation of NADPH oxidase (Nox2) by lipid rafts in breast carcinoma cells. Int J Oncol. 2010;37(6):1483-93.

74. Jo Y-Y, Kim D-W, Choi J-Y, Kim S-G. 4Hexylresorcinol and silk sericin increase the expression of vascular endothelial growth factor via different pathways. Scientific reports. 2019;9(1):3448.

75. Rosen GM, Pou S, Ramos CL, Cohen MS, Britigan BE. Free radicals and phagocytic cells. FASEB J. 1995;9(2):200-9.

76. Kwakye GF, Jiménez JA, Thomas MG, Kingsley BA, McIivin M, Saito MA, et al. Heterozygous huntingtin promotes cadmium neurotoxicity and neurodegeneration in striatal cells via altered metal transport and protein kinase $\mathrm{C}$ delta dependent oxidative stress and apoptosis signaling mechanisms. Neurotoxicology. 2019;70:48-61.

77. Kasetty G, Papareddy P, Kalle M, Rydengård V, Mörgelin M, Albiger B, et al. Structure-activity studies and therapeutic potential of host defense peptides of human thrombin. Antimicrob Agents Chemother. 2011;55(6):2880-90.

78. Vieira GLT, Lossie AC, Lay DC, Jr., Radcliffe JS, Garner JP. Preventing, treating, and predicting barbering: A fundamental role for biomarkers of oxidative stress in a mouse model of Trichotillomania. PLoS One. 2017;12(4):e0175222.

79. Bevara GB, Naveen Kumar AD, Koteshwaramma KL, Badana A, Kumari S, Malla RR. C-glycosyl flavone from Urginea indica inhibits proliferation $\&$ angiogenesis $\&$ induces apoptosis via cyclindependent kinase 6 in human breast, hepatic \& colon cancer cell lines. Indian J Med Res. 2018;147(2):158-68.

80. Gayatri Devi V, Badana A, Kumari S, Nagaseshu P, Malla R. Therapeutic potentials of CD151 shRNA in targeting metastasis of triple negative breast cancer cell line MDA-MB-231. J Cancer 
Sci Ther. 2016;8(4):104-12.

81. Devi G, Badana A, Madhuri Ch MMP, Naik S. Knockdown of CD151 Gene Expression Reduces Survival of Estrogen Receptor Positive Breast Cancer Cells. J Clin Exp Oncol 6. 2017:4:2.

82. Comeau SR, Gatchell DW, Vajda S, Camacho CJ. ClusPro: a fully automated algorithm for protein-protein docking. Nucleic Acids Res. 2004;32(Web Server issue):W96-9.

83. Jiménez-García B, Pons C, Fernández-Recio J. pyDockWEB: a web server for rigid-body protein-protein docking using electrostatics and desolvation scoring. Bioinformatics. 2013;29(13):1698-9.

84. Conde de la Rosa L, Schoemaker MH, Vrenken TE, Buist-Homan M, Havinga R, Jansen PL, et al. Superoxide anions and hydrogen peroxide induce hepatocyte death by different mechanisms: involvement of JNK and ERK MAP kinases. Journal of hepatology. 2006;44(5):918-29.

85. Kim EH, Choi KS. A critical role of superoxide anion in selenite-induced mitophagic cell death. Autophagy. 2008;4(1):76-8.

86. Park S, Kim JA, Choi S, Suh SH. Superoxide is a potential culprit of caspase-3 dependent endothelial cell death induced by lysophosphatidylcholine. Journal of physiology and pharmacology : an official journal of the Polish Physiological Society. 2010;61(4):375-81.

87. Muller FL, Liu Y, Van Remmen H. Complex III releases superoxide to both sides of the inner mitochondrial membrane. J Biol Chem. 2004;279(47):49064-73.

88. Jastroch M, Divakaruni AS, Mookerjee S, Treberg JR, Brand MD. Mitochondrial proton and electron leaks. Essays in biochemistry. 2010;47:53-67.

89. Brand MD. Mitochondrial generation of superoxide and hydrogen peroxide as the source of mitochondrial redox signaling. Free Radic Biol Med. 2016;100:14-31.

90. Lu Y, Liu Y, Yang C. Evaluating In Vitro DNA Damage Using Comet Assay. J Vis Exp. 2017(128):56450.

91. Liu LX, Lu JC, Zeng HY, Cai JB, Zhang PF, Guo XJ, et al. Mortalin stabilizes CD151-depedent tetraspanin-enriched microdomains and implicates in the progression of hepatocellular carcinoma. Journal of Cancer. 2019;10(25):6199206.

92. Koteswari LL, Kumari S, Kumar AB, Malla RR. A comparative anticancer study on procyanidin C1 against receptor positive and receptor negative breast cancer. Natural product research. 2019:1-8.

93. Kang JS, Choi IW, Han MH, Lee DS, Kim GY, Hwang HJ, et al. The Cytoprotective Effect of
Petalonia binghamiae Methanol Extract against Oxidative Stress in C2C12 Myoblasts: Mediation by Upregulation of Heme Oxygenase1 and Nuclear Factor-Erythroid 2 Related Factor 2. Marine drugs. 2015;13(5):2666-79.

94. Yagasaki M, Hashimoto S-i, biotechnology. Synthesis and application of dipeptides; current status and perspectives. Applied microbiology and biotechnology 2008;81(1):13.

95. Kaul S, Sharma SS, Mehta IK. Free radical scavenging potential of L-proline: evidence from in vitro assays. Amino acids. 2008;34(2):315-20.

96. Alia, Mohanty P, Matysik J. Effect of proline on the production of singlet oxygen. Amino acids. 2001;21(2):195-200.

97. Smirnoff N, Cumbes QJJP. Hydroxyl radical scavenging activity of compatible solutes. Phytochemistry. 1989;28(4):1057-60.

98. Phang JM, Donald SP, Pandhare J, Liu Y. The metabolism of proline, a stress substrate, modulates carcinogenic pathways. Amino acids. 2008;35(4):681-90.

99. Barbul A. Proline precursors to sustain Mammalian collagen synthesis. The Journal of nutrition. 2008;138(10):2021s-4s.

100.Wu G, Bazer FW, Burghardt RC, Johnson GA, Kim SW, Li XL, et al. Impacts of amino acid nutrition on pregnancy outcome in pigs: mechanisms and implications for swine production. Journal of animal science. 2010;88(13 Suppl):E195-204.

101.Giessen TW, Marahiel MA. Rational and combinatorial tailoring of bioactive cyclic dipeptides. Frontiers in microbiology. 2015;6:785.

102. Yan PS, Song Y, Sakuno E, Nakajima H, Nakagawa H, Yabe K. Cyclo(L-leucyl-L-prolyl) produced by Achromobacter xylosoxidans inhibits aflatoxin production by Aspergillus parasiticus. Applied and environmental microbiology. 2004;70(12):7466-73.

103.Zimmerman SS, Scheraga HA. Stability of cis, trans, and nonplanar peptide groups. Macromolecules. 1976;9(3):408-16.

104.Deslauriers R, Grzonka Z, Walter R. Influence of $\mathrm{D}$ and $\mathrm{L}$ amino-acid residues on the conformation of peptides in solution: A carbon13 nuclear magnetic resonance study of cyclo(prolyl-leucyl). Biopolymers. 1976;15(9):1677-83.

105. Shimura H, Tanaka R, Shimada Y, Yamashiro K, Hattori N, Urabe T. Glycyl-alanyl-histidine protects PC12 cells against hydrogen peroxide toxicity. BMC biochemistry. 2017;18(1):14.

106.Kang M, Ryu J, Lee D, Lee MS, Kim HJ, Nam $\mathrm{SH}$, et al. Correlations between transmembrane 4 L6 family member 5 (TM4SF5), CD151, and CD63 in liver fibrotic phenotypes and hepatic migration and invasive capacities. PLoS One. 
2014;9(7):e102817.

107. Wadkin JCR, Patten DA, Kamarajah SK, Shepherd EL, Novitskaya V, Berditchevski F, et al. CD151 supports VCAM-1-mediated lymphocyte adhesion to liver endothelium and is upregulated in chronic liver disease and hepatocellular carcinoma. American journal of physiology Gastrointestinal and liver physiology. 2017;313(2):G138-g49.

108. Bae YS, Kang SW, Seo MS, Baines IC, Tekle E, Chock PB, et al. Epidermal growth factor (EGF)-induced generation of hydrogen peroxide Role in EGF receptor-mediated tyrosine phosphorylation. Journal of Biological Chemistry. 1997;272(1):217-21. 